\title{
Jean-Paul Gavard-Perret, L'imaginaire paradoxal ou la création absolue dans les ceuvres dernières de Samuel Beckett
}

\section{Emanuele Kanceff}

\section{(2) OpenEdition \\ 12 Journals}

\section{Edizione digitale}

URL: https://journals.openedition.org/studifrancesi/41201

DOI: $10.4000 /$ studifrancesi. 41201

ISSN: 2421-5856

\section{Editore}

Rosenberg \& Sellier

\section{Edizione cartacea}

Data di pubblicazione: 1 juillet 2004

Paginazione: 221

ISSN: 0039-2944

\section{Notizia bibliografica digitale}

Emanuele Kanceff, «Jean-Paul Gavard-Perret, L'imaginaire paradoxal ou la création absolue dans les œuvres dernières de Samuel Beckett», Studi Francesi [Online], 142 (XLVIII | I) | 2004, online dal 30 novembre 2015, consultato il 09 septembre 2021. URL: http://journals.openedition.org/studifrancesi/ 41201 ; DOI: https://doi.org/10.4000/studifrancesi.41201

Questo documento è stato generato automaticamente il 9 septembre 2021.

\section{cc) $($ ) $\ominus$}

Studi Francesi è distribuita con Licenza Creative Commons Attribuzione - Non commerciale - Non opere derivate 4.0 Internazionale. 


\title{
Jean-Paul Gavard-Perret, L'imaginaire paradoxal ou la création absolue dans les œuvres dernières de Samuel Beckett
}

\author{
Emanuele Kanceff
}

\section{NOTIZIA}

Jean-Paul Gavard-Perret, L'imaginaire paradoxal ou la création absolue dans les œuvres dernières de Samuel Beckett, Paris-Caen, Lettres Modernes Minard, 2001, pp. 258 («Bibliothèque Circé», 3).

1 Nella collezione «Circé» diretta da Jean Burgos esce questo elegante e formalmente ricercato volume sulla produzione ultima dell'estroso e "paradossale» scrittore, che vuol porre rimedio alla troppo limitata conoscenza che si ha di una parte eminentemente creativa dell'opera di Beckett.

2 Ciò è tanto più grave in quanto, dice l'autore, queste opere rappresentano la conclusione dell'evoluzione problematica che lo scrittore ha conosciuto ed espresso nei propri scritti e permettono di comprenderne meglio il significato e l'originalità.

3 Tali opere, inoltre, rappresentano l'abbandono dei generi tradizionali per creare un immaginario rispetto al quale la stessa nozione di genere scompare. È questo Imaginaire sans images che l'autore si applica ad illustrare, con il concorso di cinema e televisione. 